\title{
THE CHIEF AND HIS SACRAL POWER
}

\begin{abstract}
The emergence of the chiefdom is associated with a qualitative change in the nature of political power. Unlike the bigman, who was constantly forced to prove the right on the authority by his actions, the chief uses to strengthen his authority a new, unprecedented means. He becomes the mediator between the community members and the deities, and largely because of this he increasingly distances himself from the bulk of the congregation. Often the chief transferred his functions to assistants, that to deduce himself from the blow of criticism for mistakes and miscalculations of his policy, taking the role of the sacral authority owner. The chief's authority has strengthened even more due to the fact that the chief often have arrogated to oneself the right to carry out religious rites.

Occupying a central place in the political, social and cultural life of the archaic society, representing the stability and the prosperity, the chiefs became a sort of pivot point for the whole structure of the worldview of the ancient human. As such, the chief appropriated additional symbolic resource which he used to further consolidate his power. He surrounded himself with professional assistants and soldiers, he strengthened institutions for the transfer of power. Thus, the sacralization of the chief's power becomes an important condition of the society's transformation from chiefdom to more complex form of social organization - to the early state.
\end{abstract}

Keywords: the authority, the archaic society, the chief, the chiefdom, the sacral power.

The emergence of the chiefdom is associated with a qualitative change in the nature of political power. Unlike the bigman, who was constantly forced to prove the right on the authority by his actions, the chief uses to strengthen his authority a new, unprecedented means. He becomes the mediator between the community members and the deities, (Claessen 1978; Kradin 1995: 47) and largely because of this he increasingly distances himself from the bulk of the congregation.

The abilities of the chief to possess the sacral power found the most complete forms of one's incarnations, probably in the societies of Central Asian nomads. There the chief had such a high social position that he often distanced from worldly affairs, by transferring their jurisdiction to the deputy. P. B. Golden, said the following: "There were created explicitly sacred system of dual power in the Khazar khanate. "Senior", or "greatest" ruler, the Khagan, was only a ceremonial figure... "Junior" the Governor, the Deputy of Kagan ... in reality solved the affairs of the khanate, commanded the troops. This trend in the development of the institution Hagan to a certain extent even earlier was used by the Turks". (Gil'ferding 1855: 223)

But the distancing the chief from worldly affairs did not mean that he does lose his power and control over his congregation. On the contrary, transferring his functions to assistants, the chief thereby deduced themselves from the blow of criticism for mistakes and miscalculations of their policy, taking on the role 
of the sacral authority owner. It was strengthened even more due to the fact that the Central Asian nomads' chiefs have often arrogated to oneself the right to carry out religious rites.

For example, the chiefs of the Xiongnu conducted sacrifices, which were related to the occurrence of particularly significant events - such as the conclusion of an agreement, oath of office, Declaration of war etc So, ancient records say that "Chan Myn, shanyu and his elders went up into the mountain of the Huns on the Eastern side of the river No-Shui and has killed a white horse. Shanyu has taken the road sword, and has soaked its spearhead in a wine; they solemnly drank wine from the skull of the head of the Yacheist Emperor, who was killed by Laoshan-shanyu". (Bichurin 1998: 94)

The shanyu also performed daily rituals and rites addressed to the celestial bodies. Chronicles say it this way: "in the Morning shanyu exited out of the bet to perform the worship for the rising sun, and in the night, for performing of worship the moon." (Materialy... 1968: 40-41)

The ancient Chinese chronicle "Josho" also says that similar functions were vested on Turkic kagans: "Every year Khagan led nobles to the cave of the ancestors to make sacrifices, and in the middle decade of the 5-th month they gathered near the river Tamir to sacrifice to the God of Heaven." (Potapov 1991: 122-123)

One can detect leaders-priests also in societies of the Uighurs, the Naimans, the Kipchaks and the Kanglies, etc. (Potapov 1991: 122-123) Thus, we can agree with the opinion of the Chinese historian Liu Mauza that the nomads' leaders may be considered as "the Supreme spiritual person of the state" and "his sovereign authority flowed from the magic power." (Potapov 1991: 122-123)

It is important to understand that the resources of sacral power were owned to the Supreme rulers in most traditional societies. (Kradin 2001: 162) And this statement is fair also in relation to the settled people. These resources stemmed from the belief of the subjects of the leader in his mystical powers.

In societies of farmers the chief often used his superhuman strength to maintain the fertility of the land. Summarizing the observations of anthropologists in archaic cultures, J.Fraser wrote: "Most of tribal leaders are makers of rain, and their popularity is depending on the ability to call for his people the rain at the right time of the year. Wanting to cause rain, the sorcerer plunges the stones in water, takes in hand the purified from the bark of the stick, makes for the clouds come-hither sign or drives them in the right direction, muttering the spell. Or he pours the water in a depression in the stone and plunges in it the entrails of a sheep or goat, and then sprays water in the air." (Frezer 2001: 118-119)

Similar views prevailed among the ancient people. For example, the ancient Greeks in the Homeric period believed that the ruler provides them the abundance. This is reflected in the "Odyssey". (Od., XIX: 111-114) Probably we should agree with M. Nilson, who believed that perceptions of the leader as the giver of wealth existed in the Mycenaean culture. (Nilsson 1933: 220) In a similar way the beliefs in the mystical power of the leader were represented in the Indian "Mahabharata". Here the Supreme ruler also provides irrigation of the land by rain. (Vasil'kov 1979: 112; Romanov 1991) We can see similar beliefs in other ancient cultures. (Eliade 1995; Sidahome 1964; Tumans 2002: 134-135)

In chiefdoms, which wealth was based on the seizure of foreign economic resources, the chief has gained mystical qualities of brave and successful grappler and commander. (Puzanov 2007: 126-127) This is not surprising, because the unpredictability of the soldier's fate during the clashes gave rise to belief in his luck, which in a large degree is determined by happiness and good fortune of his military leader. (Gurevich 2005: 17) 
The belief in mystical powers of a military leader was so strong among the ancient people, that they endowed their leaders with superhuman abilities. For example, according to the mythology of the Caucasian princes, chief's families have assistants, the spirits-genies, who gave magical power to the aristocrats. With their help, according to Balkar legend, Princess Meleese Bicanova sent damage to his nephews, Digor princes the Kubedievs. Jinns have appeared before them from the "lower world", after which the young Princes have contracted with a severe disease (кетмез ит ауруy). (Eski dzhyrla: 282-283)

Ethnographic information about the supernatural abilities of chiefs are in good agreement with the historical.

For example, in Russia "motif ....of the light emanating from the Prince to the people, too often found in the literature... the Light from the Prince ... like a divine light, in fact, is his emanation. Prince is the translator of this divine light to the people.... The divine light is an attribute of Christ, therefore Prince, in a certain sense, is a Superman, is a demigod." (Tolochko 1994: 18-19)

Similarly, the Franks believed that their leader Clovis had supernatural powers. According to the testimony of Gregory of tours, "the Lord gave Clovis such heavenly grace, that walls themselves were crumbling from one his look". (Kradin 2001: 33) It is noteworthy that not only Western authors (Pavel Diakon: 488-489) believed in the powers of their leaders. It is known that even well-educated and rational the Byzantines have such beliefs. (Prokopii Kessariiskii: 194-196) They also believed that even a powerful state can fall to the feet of the commander who is resolute and endowed with mystical power. (Puzanov 1997: 126-127)

Interestingly, societies in various parts of the world and at different times believed in space forces of their rulers the. One should agree with the opinion that "in early societies, the monarch - not so much the product of social development, as the ritual figure. Therefore we can see a sanctification of the person of the Keeper, as the center of the cosmic order and as the impersonation of the collective." (Tolochko 1992: 15)

If, according to ancient beliefs, the leader was able to ensure the maintenance of universal harmony, it seems natural, that he ranked in a central position of the world order, which was given to him by mythology. For example, "song of creation" of Kumulipo tells about the formation of the world from darkness to light and from chaos to order. The order of the world is embodied in the social order, and that, in turn, is represented in the form of a single whole body. In this body the Supreme chief was as its head, his subordinate chiefs were as the shoulders and chest, the high priest of the Kahuna Nui was as a right hand and Advisor to the Supreme leader kalamaku - as left hand. Body relied on the legs, the right of which was the soldiers, and left - the fishermens and the peasants. (The Kumulipo 1951)

Occupying a central place in the political, social and cultural life in archaic society, representing the stability and the prosperity, the chiefs became a sort of pivot point for the whole structure of the worldview of the ancient human. There is therefore nothing strange in the fact that the death of the leader became an extraordinary event for society. It plunged the people into confusion, and demanded that they find ways to express their grief, which would be adequate to the severity of the loss incurred.

Not accidentally, that funerary cults has taken an important place in the spiritual life of chiefdoms. They were designed to perpetuate the memory of the departed chief and to provide him with some ritual of transition to the spirit world and comfortable stay in the afterlife, but, equally important, to 
demonstrate them dread before the face of the coming chaos and darkness and to propitiate the departed leader by expression of despair and grief.

For example, according to Herodotus, before the burial of their leaders Scythians embalmed the deceased and showed him to his former subjects during a funeral ceremony of farewell detour in the farthest corners of the steppe Empire. Meeting a funeral procession, the Scythians expressed the severity of the loss. They inflicted the wounds, tore those clothes, pulled hair, and bitterly wept. At the conclusion of a farewell detour one must bury the leader. His body was placed in the burial chamber, around which were built the funerary complex, symbolizing the unity of the living and the deceased. (Gerodot 1972: 71) Often these buildings became centers around which were regularly performed elaborate rituals. An example of such sacred centers are the Pazyryk burials of Altai, which apparently, repeatedly used by nomads as cameras-chapels. (Savinov 1997: 30-39)

Such worship of deceased chiefs probably can be explained that after death they did not lose their sacred power over the living, and had the ability to influence the fate of mortals.

In some cultures the people were so believed in sacral powers of died chiefs that they invaded in the halls of the dead lords in the hope that they will hear their appeals and satisfy the requests. Of course, the grave-robbers were often invaded into the peace of the dead with the purpose of personal enrichment. But often their purpose was another - to take forces of "farn" or "mana", which contained in the remains of a great warrior. (Khazanov, Chernenko 1979) In some cultures, people at all saved themselves from having to invade in the tombs of the deceased chiefs, in advance of making the "lines of communication" with them. For example, this was done by Mayans in the first Millennium BC. The contact with the deceased chiefs implemented either remotely through the stone pipe, or directly with help of the internal staircase which led down to the chief's remains, as that was done in the burial of the high priest at Chichen Itza. (Guljaev 1990: 164-170)

Gaspar Antonio Chi who was one of the members of the genus of the Tutul-Sivs, which ruled the Maya, told about the rituals of the cult of the dead chiefs before the Spanish conquest of America. According his words the main idols which the Maya made sacrifices were statues of men in their natural form, who were outstanding and brave people, and which they called, so who were able to help them in the war, to bestow prosperity and extend their lives. (Thompson 1954: 41)

Spanish Bishop Diego de Landa complements this information. He describes religious practices, which could have shocked the Christian. For example, he wrote that the Maya "separated the head of dead seniors of the ancient family Cocom, then boiled the heads and cleansed it from the meat; then sawed off the back half of the skull, leaving the face with the jaws and teeth. Then they replaced on these parts the missing meat with a special resin and did them very similar as they were during the life. Maya held them together with their idols, with great reverence and awe. In the days of their feasts and amusements they offered them the dishes, that they have had a food in the other life, where, as they thought, rested their souls, that they were able to use their gifts". (De Landa 1955: 163-164)

However, even after the arrival of the Spaniards, despite their terror against the pagans, Indians some time kept cults of the dead chiefs. So, the Spanish chronicler Juan de Villagethere Soto-Major, suggests that the chiefdom of Tayasal, who had taken refuge in the jungles of Northern Guatemala until 1697 kept the cults of veneration of the dead. He writes that the Indians "worshipped their dead kings like Gods ", (de Cogolludo 1964: 355) and in their capital was located a large sanctuary, owned by the 
Governor Kaneko and his ancestors who were once kings in the province of Yucatan. (de Villagutierre Soto-Mayor 1933: 387)

The foregoing allows to conclude that the leaders of the era of chiefdom were not only endowed with the broadest political, economic and military-administrative authority, but also were a carrier of sacred power. Ancient people believed that they possessed superhuman powers and thus guaranteed the well-being of the group. The chiefs personified the power and the world of cosmic harmony, and in this capacity they have not only abilities to act as a mediator between people and higher powers, but even became equal to God.

Occupying a central place in the political, social and cultural life of the archaic society, representing the stability and the prosperity, the chiefs became a sort of pivot point for the whole structure of the worldview of the ancient human. Possessing with sacral power the chief was able more confidently to fulfill his secular functions. The chief was separated from the community members by considerable social distance. He appropriated the right to be the mediator between the community members and the deities, the right to appeal to the gods and to perform sacrifices and became living embodiment of prosperity, order and world harmony. As such, the chief appropriated additional symbolic resource which he used to further consolidate his power. He surrounded himself with professional assistants and soldiers, he strengthened institutions for the transfer of power. Thus, the socialization of the chief's power becomes an important condition of the society's transformation from chiefdom to more complex form of social organization - to the early state.

\section{REFERENCES}

Bichurin, N.Ya. (1998). Sobranie svedenija o narodah, obitavshih v Srednej Azii, v drevnie vremena (Collection of information about peoples that lived in Central Asia in ancient times). T. 1. Almaty. Claessen, H.Y.M. (1978). The Early State: A Structural Approach // H.Y.M. Claessen, P. Skalnik (eds.) The Early State. The Haague; Paris; N.Y.

de Cogolludo, L. (1954). Historia de Yucatan. T. 1. Campeche.

de Villagutierre Soto-Mayor, J. (1933). Historia de la conquista de la provincial de el Itza. Guatemala.

De Landa, D. (1955). Soobshheniya o delakh v Yukatane (Reports about Affairs in the Yucatan). Moskva, Leningrad.

Eliade, M. (1995). Aspekty mifa (Aspects of the myth). Moskva.

Eski dzhyrla (1993). Starinnye pesni (Old Songs). Mingi-Tau. № 4(50).

Frezer, Dzh. (2001). Zolotaja vetv': Issledovanie magii i religii (The Golden Bough: A Study of Magic and Religion). V 2 t. Per. s angl. M. Ryklina. M.: TERRA-Knizhnyj klub.

Gerodot (1972). Istoriya v devyati knigah (History in Nine Books). Per. i prim. G.I. Stratanovskogo. Kn. IV. Leningrad.

Gil'ferding A.F. (1855). Istoriya baltiiskikh slavyan (History of the Baltic Slavs). T. 1. Moskva.

Guljaev, V.I. (1990). Gosudarstvennaya ideologiya drevnikh maiya (k voprosu o kul'te carskikh predkov) (State Ideology of the Ancient Maya (on the question of the cult of the king's ancestors)). Problemy arkheologii i drevnei istorii stran Latinskoi Ameriki. Moskva. 
Gurevich, A.Ya. (2005). Dialektika sud'by u germancev i drevnikh skandinavov (The Dialectic of the Germans and the Fate of the Ancient Scandinavians). Mifologema zhenshhiny-sud'by u drevnikh kel'tov i germancev / Otv. red. T.A. Mihailova. Moskva.

Khazanov, A.M., Chernenko, E.V. (1979). Chas i motivi pograbuvannya skifs'kikh kurganiv (Time and Motives of Robbery of Scythian Burial Mounds). Arkheologiya. Kiïv. № 30.

Kradin, N.N. (1995). Vozhdestvo: sovremennoe sostoyanie i problemy izucheniya (Chiefdom: Current Status and Problems of Study). Rannie formy politicheskoi organizacii: ot pervobytnosti $k$ gosudarstvennosti. Otv. red. V.A. Popov. Moskva.

Kradin, N.N. (2001). Politicheskaya antropologiya (Political Anthropology). Ucheb. posobie. Moskva.

Materialy po istorii syunnu (po kitaiskim istochnikam) (Materials on the history of the Huns (by Chinese sources)) (1968). Per. i prim. V.S. Taskina. Vyp. 1. Moskva.

Nilsson, M. (1933). Homer and Mycenae. London.

Od., XIX.

Pavel Diakon. Istorija langobardov (History of the Lombards). Svod 2.

Potapov, L.P. (1991). Altaiskii shamanism (Altai Shamanism). Leningrad.

Prokopii Kessariiskii. Istoriya voin (The History of Wars). Svod 1.

Puzanov, V.V. (2007). Drevnerusskaya gosudarstvennost': genezis, etnokul'turnaya sreda, ideologicheskie konstrukty ((Old Russian Statehood: the Genesis, Ethno-cultural Environment, Ideological Constructs). Izhevsk.

Puzanov, V.V. (1997). U istokov vostochnoslavyanskoi gosudarstvennosti (At the Root of the East Slavic Statehood). Istoriya Rossii: Narod i vlast'. Sankt-Peterburg.

Romanov, V.N. (1991). Istoricheskoe razvitie kul'tury (The Historical Development of Culture. Typology of Problems). Problemy tipologii. Moskva.

Savinov, D.G. (1997). Pogrebal'nye kamery-«chasovni» Bol'shikh Pazyrykskikh kurganov (Funeral Box"Chapels" of the Great Pazyryk Mounds). Sakral'noe v istorii kul'tury. Sankt-Peterburg.

Sidahome, Y.E. (1964). Stories of the Benin Empire. London; Ibadan.

The Kumulipo (He Kumulipo no ka I-i-mamao a i Alapai-wahine). (1951). / Ed. By Beckwith M.W. Chicago: Chicago University Press.

Thompson, J.E.S. (1954). The Rise and Fall of Maya Civilization. Norman: University of Oklahoma Press.

Tolochko, A.P. (1992). Knyaz' v Drevnei Rusi: vlast', sobstvennost', ideologiya (The Prince in Ancient Russia: Power, Property, Ideology). Kiev.

Tolochko, O.P. (1994). Rus': derzhava i obraz derzhavi (Ancient Russia: Power and the Image of Power). Kiïv.

Tumans, H. (2002). Rozhdenie Afiny. Afinskii put' k demokratii: ot Gomera do Perikla (Birth of Athena. Athens Way to Democracy: from Homer to Pericles). Sankt-Peterburg.

Vasil'kov, Ya.V. (1979). Zemledel'cheskii mif v drevneindiiskom epose (Skazanie o Rish'yashringe) (Agricultural myth in ancient Indian epos (The Legend of Rishyashring)). Literatura i kul'tura drevnei i srednevekovoi Indii. Moskva. 